\title{
Carbohydrate Accumulation in Relation to Heat Stress Tolerance in Two Creeping Bentgrass Cultivars
}

\author{
Xiaozhong Liu ${ }^{1}$ and Bingru Huang ${ }^{2}$ \\ Department of Horticulture, Forestry, and Recreation Resources, Kansas State University, Manhattan, \\ $K S, 66506$
}

\begin{abstract}
AdDitional IndEX wORDs. Agrostis stolonifera var. palustris, Agrostis palustris, root mortality, total nonstructural carbohydrates, turf quality
\end{abstract}

\begin{abstract}
Understanding physiological factors that may confer heat tolerance would facilitate breeding for improvement of summer turf quality. The objective of this study was to investigate whether carbohydrate availability contributes to changes in turf quality and root mortality during heat stress in two creeping bentgrass [Agrostis stolonifera $\mathrm{L}$. var. palustris (Huds.) Farw. (syn. A. palustris Huds.)] cultivars, 'L-93' and 'Penncross', that contrast in heat tolerance. Grasses were grown at 14-hour days and 11-hour nights of $22 / 16{ }^{\circ} \mathrm{C}$ (control) and $35 / 25{ }^{\circ} \mathrm{C}$ (heat stress) for 56 days in growth chambers. Turf quality decreased while root mortality increased under heat-stress conditions for both cultivars, but to a greater extent for 'Penncross' than ' $L-93$ '. The concentrations of total nonstructural carbohydrate (TNC), fructans, starch, glucose, and sucrose in shoots (leaves and stems) and roots decreased at $35 / 25^{\circ} \mathrm{C}$. The reduction in carbohydrate concentrations of shoots was more pronounced than that of roots. Shoot glucose and sucrose concentrations were more sensitive to heat stress than other carbohydrates. 'L-93' maintained significantly higher carbohydrate concentrations, especially glucose and sucrose, than 'Penncross' at $35 / 25^{\circ} \mathrm{C}$. Results suggest that high carbohydrate availability, particularly glucose and sucrose, during heat stress was an important physiological trait associated with heat-stress tolerance in creeping bentgrass.
\end{abstract}

Indirect high temperature stress limits use of cool-season grasses in transitional and warm climatic regions (Beard, 1997; Beard and Daniel, 1965; Carrow, 1996). The optimum temperatures for cool-season turfgrasses range from 15 to $24^{\circ} \mathrm{C}$ for shoot growth, and 10 to $18^{\circ} \mathrm{C}$ for root growth (Beard, 1973). However, summer ambient temperatures often approach or exceed $30^{\circ} \mathrm{C}$ in transitional and warm climatic regions. Supraoptimal temperatures cause root dieback and inhibit leaf growth, tiller production, and shoot density in creeping bentgrass [Agrostis stolonifera var. palustris (syn. A. palustris)] (Carrow, 1996; DiPaola and Beard, 1992; Huang et al., 1998a, 1998b; Krans and Johnson, 1974). Shoots of Kentucky bluegrass (Poa pratensis L.) grow most actively at $22^{\circ} \mathrm{C}$, and growth decreases to less than half of the maximum at $35^{\circ} \mathrm{C}$; root growth declines as temperature increases to $25^{\circ} \mathrm{C}$ (Baker and Jung, 1968). Wehner and Watschke (1981) reported that high temperature caused direct heat injury in Kentucky bluegrass, perennial ryegrass (Lolium perenne L.), and annual bluegrass (Poа апnиа L.), with initial injury observed at $41{ }^{\circ} \mathrm{C}$ and complete kill occurred at 47 to $49^{\circ} \mathrm{C}$.

Maintenance of turf quality during heat stress may be related largely to levels of carbohydrate accumulation because carbohydrates serve as energy reserves and provide carbon skeletons for both catabolic and anabolic reactions. High temperature reduces photosynthesis but increases respiration, leading to an imbalance between the two processes in creeping bentgrass (Carrow, 1996; Huang and Gao, 1999; Huang et al., 1998a). Youngner and Nudge

Received for publication 9 Sept. 1999. Accepted for publication 11 Mar. 2000 Kansas Agricultural Experiment Station contribution 99-456-J. Research was supported by the Golf Course Superintendent Association of America, Kansas Turfgrass Foundation, and Alfred Sloan Foundation. The cost of publishing this paper was defrayed in part by the payment of page charges. Under postal regulations, this paper therefore must be hereby marked advertisement solely to indicate this fact.

${ }^{1}$ Graduate research assistant.

${ }^{2}$ Assistant professor, corresponding author.
$(1968,1976)$ reported a negative relationship between temperature and total nonstructural carbohydrates (TNC) in shoots of several turfgrass species. Watschke et at. (1970) also reported that high temperature injury was related to reduction in sugar concentration in shoots of Kentucky bluegrass. In contrast, Duff and Beard (1974) reported that in creeping bentgrass, carbohydrate content increased with increasing temperatures. The effects of heat stress on carbohydrate status in cool-season grasses remains unclear. Furthermore, extremely limited information is available on the status of different fractions of carbohydrates in shoots and roots associated with heat tolerance of creeping bentgrass. Understanding the influence of heat stress on carbohydrate metabolism in cool-season grasses and the differences among cultivars will provide better insight into mechanisms affecting plant tolerance to heat. Therefore, the following research was conducted to investigate the status of different carbohydrate fractions in shoots and roots in relation to heat tolerance in two creeping bentgrass cultivars, 'L-93' and 'Penncross', that contrast in heat tolerance (Huang et al., 1998a, 1998b).

\section{Materials and Methods}

Plant materials. Two-year-old sod of 'L-93' and 'Penncross' creeping bentgrass was removed in May 1999 from field plots at the Rocky Ford Turfgrass Research Center, Kansas State Univ., Manhattan. The sod of each cultivar was planted in polyvinyl chloride tubes $(20 \mathrm{~cm}$ in diameter and $60 \mathrm{~cm}$ in length), which were filled with a medium of $10 \%$ fritted clay (Profile, AIMCOR, Deerfield, Ill.) and $90 \%$ coarse sand (by volume). Turf was mowed daily to a $4 \mathrm{~mm}$ height with an electric clipper, irrigated once daily with tap water until there was free drainage from the bottom of tubes, and fertilized weekly with $40 \mathrm{~mL}$ full-strength Hoagland's (Hoagland and Arnon, 1950) nutrient solution (Hoagland and Arnon, 1950).

TreatMEnTs. Grasses of the same age transplanted from field 
Table 1. Analysis of variance (ANOVA) for various leaf parameters as affected by high temperature in two creeping bentgrass cultivars.

\begin{tabular}{|c|c|c|c|c|c|c|c|}
\hline $\begin{array}{l}\text { Source of } \\
\text { variation }\end{array}$ & $\mathrm{df}$ & Quality & $\mathrm{TNC}^{\mathrm{z}}$ & Fructans & Starch & Sucrose & Glucose \\
\hline$\overline{\text { Cultivar (C) }}$ & 1 & $* * * *$ & $* * * *$ & $* * * *$ & $* * * *$ & $* * * *$ & $* * * *$ \\
\hline Temperature $(\mathrm{T})$ & 1 & $* * * *$ & $* * * *$ & $* * * *$ & $* * * *$ & $* * * *$ & $* * * *$ \\
\hline Time & 3 & $* * * *$ & $* * * *$ & $* * * *$ & $* * * *$ & $* * * *$ & $* * * *$ \\
\hline Replication & 3 & NS & NS & NS & NS & NS & NS \\
\hline $\mathrm{C} \times \mathrm{T}$ & 1 & $* * * *$ & $* * * *$ & $* * * *$ & $* * * *$ & $* * * *$ & $* * * *$ \\
\hline $\mathrm{C} \times$ time & 3 & NS & $*$ & $* * *$ & $* * * *$ & NS & NS \\
\hline $\mathrm{T} \times$ time & 3 & $* * * *$ & $* * * *$ & $* * * *$ & $* * * *$ & $* * * *$ & $* * * *$ \\
\hline $\mathrm{C} \times \mathrm{T} \times$ time & 3 & NS & $*$ & $* * * *$ & $* * * *$ & $*$ & $* * * *$ \\
\hline
\end{tabular}

${ }^{\mathrm{z}} \mathrm{TNS}=$ total nonstructural carbohydrates.

$\mathrm{NS},{ }^{*}, * * *, * * * * * N$ Nonsignificant or significant at $P<0.05,0.001$, or 0.0001 , respectively.

Table 2. Analysis of variance (ANOVA) for various root parameters as affected by high temperature in two creeping bentgrass cultivars.

\begin{tabular}{|c|c|c|c|c|c|c|c|}
\hline $\begin{array}{l}\text { Source of } \\
\text { variation }\end{array}$ & df & Mortality & $\mathrm{TNC}^{\mathrm{z}}$ & Fructans & Starch & Sucrose & Glucose \\
\hline$\overline{\text { Cultivar (C) }}$ & 1 & $* * * *$ & $* * * *$ & $* * * *$ & $* * * *$ & $* * * *$ & $* * *$ \\
\hline Temperature $(\mathrm{T})$ & 1 & $* * * *$ & $* * * *$ & $* * * *$ & $* * * *$ & $* * * *$ & $* * * *$ \\
\hline Time & 3 & $* * * *$ & $* * * *$ & $* * * *$ & $* * * *$ & $* * * *$ & $* * * *$ \\
\hline Rep. & 3 & NS & NS & $* *$ & NS & NS & NS \\
\hline $\mathrm{C} \times \mathrm{T}$ & 1 & $* * * *$ & $*$ & $* * * *$ & $* * * *$ & $* * * *$ & $* * * *$ \\
\hline $\mathrm{C} \times$ time & 3 & $* * *$ & $* *$ & NS & NS & NS & NS \\
\hline $\mathrm{T} \times$ time & 3 & $* * * *$ & $* * * *$ & $* * * *$ & $* * * *$ & $* * * *$ & $* * * *$ \\
\hline $\mathrm{C} \times \mathrm{T} \times$ time & 3 & $* * * *$ & NS & $* * * *$ & $*$ & NS & $* * * *$ \\
\hline
\end{tabular}

${ }^{\mathrm{z} T N C}=$ total nonstructural carbohydrates.

NS,*,**,***,*****N Nonsignificant or significant at $P<0.05,0.01,0.001$, or 0.0001 , respectively.

plots were maintained in growth chambers at 14-h days and 11$\mathrm{h}$ nights of $22 / 16^{\circ} \mathrm{C}$ for $\approx 2$ months. Thereafter, half of the plants were left at $22 / 16{ }^{\circ} \mathrm{C}$ (control), and half of the plants were transferred to another set of growth chambers also maintained initially at days/nights of $22 / 16^{\circ} \mathrm{C}$. However, over a 3-d period day/night temperatures were increased daily by 4 to $5^{\circ} \mathrm{C}$ until reaching $35 / 25^{\circ} \mathrm{C}$ (heat stress). Grasses were irrigated daily and fertilized weekly with Hoagland's solution while being exposed to heat stress for $56 \mathrm{~d}$. Growth chambers were set at a 14-h photoperiod provided by fluorescent and incandescent lamps, which provided a photosyntheticphoton flux of $600 \mu \mathrm{mol} \cdot \mathrm{m}^{-2} \cdot \mathrm{s}^{-}$ ${ }^{1}$ at the canopy level, as measured with a quantum/radiometer/ photometer (LI-6400; LI-COR Inc., Lincoln, Neb.). Relative humidity was maintained at $65 \%$.

Growth MEASUREMENTS. Measurements were made at 0, 14, 28, 42 , and $56 \mathrm{~d}$ of temperature treatment. Turf visual quality was evaluated as a combination of grass density, uniformity, and color using a scale of 0 (all plants dead) to 9 (all plants green and healthy). Thereafter, shoots were removed with an electric clipper, and roots were separated from the aboveground portion and were washed free of sand. About one-thirds of roots were used to determine mortality immediately after cleaning. The remaining roots and shoots were dried at $70^{\circ} \mathrm{C}$ for $72 \mathrm{~h}$ and ground with a cyclone sample mill (UDY Corp., Fort Collins, Colo.). The samples were stored in 20-mL glass vials for carbohydrate analysis.

Root mortality was measured using the method of Knievel (1973) with modification. Samples of 1.5 to $3.0 \mathrm{~g}$ fresh roots were incubated with $20 \mathrm{~mL} 0.6 \%$ 2,3,5-triphenyltetrazolium chloride in 0.05 м phosphate buffer ( $\mathrm{pH} 7.4$ ) for $24 \mathrm{~h}$ in the dark at $30^{\circ} \mathrm{C}$. Roots were then rinsed twice with deionized water. Formazan was extracted from the roots twice with $95 \%$ ethanol at $70^{\circ} \mathrm{C}$ for $4 \mathrm{~h}$. Combined extractant from the two extractions was adjusted to a final volume of $50 \mathrm{~mL}$ with $95 \%$ ethonol. Absorbance was read at $490 \mathrm{~nm}$ with a spectrophotometer (U-1100; Hitachi Ltd., Tokyo, Japan). A standard curve was developed using different proportions of living roots and roots killed in an autoclave to calculate root mortality. Root mortality was expressed as percentage dead root dry weight (DW) of the total root DW.

Concentration of TNC, fructans, and starch were determined using the method of Chatterton et al. (1987) with modification. For TNC, 50-mg samples were hydrolyzed with $10 \mathrm{~mL} 0.1 \%$ clarase for $24 \mathrm{~h}$ at $37{ }^{\circ} \mathrm{C}$. Then, $5 \mathrm{~mL}$ of enzyme hydrolysis solution was hydrolyzed further with $0.6 \mathrm{~mol} \cdot \mathrm{L}^{-1} \mathrm{HCl}$ for $18 \mathrm{~h}$ at $22^{\circ} \mathrm{C}$. The $\mathrm{HCl}$ hydrolysis solution was adjusted to $\mathrm{pH} 5$ to 7 with $0.5 \mathrm{~m} \mathrm{NaOH}$ and diluted with distilled water to a final volume of $10 \mathrm{~mL}$. The concentration of reducing sugar was measured and was considered as TNC content. Measurement of fructans followed the same procedure used for TNC, except without $\mathrm{HCl}$ hydrolysis. The difference in reducing sugar concentrations between clarase extractions with and without $\mathrm{HCl}$ hydrolysis was calculated as fructan concentration. For starch extraction, 50-mg samples were incubated in $10 \mathrm{~mL}$ distilled water at $55^{\circ} \mathrm{C}$ for 24 h. Then $5 \mathrm{~mL}$ of solution was hydrolyzed with $0.6 \mathrm{~mol} \cdot \mathrm{L}^{-1} \mathrm{HCl}$ following the same procedure used for TNC. The reducing sugar concentration was determined. Starch concentration was calculated as the TNC concentration minus the reducing sugar concentration in the starch extraction.

Concentrations of glucose and sucrose were determined using the method of Westhafer et al. (1982). Either shoots or roots (50 $\mathrm{mg}$ ) were incubated in $10 \mathrm{~mL} 0.1 \mathrm{~m}$ phosphate buffer ( $\mathrm{pH}$ 5.4) for $24 \mathrm{~h}$ at $22{ }^{\circ} \mathrm{C}$. The supernatant was used to measure sugars. For glucose determination, a $0.2-\mathrm{mL}$ sample was mixed with $1.0 \mathrm{~mL}$ glucose oxidase (10 units) or distilled water and incubated in a water bath for $1 \mathrm{~h}$ at $50{ }^{\circ} \mathrm{C}$. The difference in reducing sugar concentrations between the incubation solutions with and without glucose oxidase was calculated as glucose concentration. The 


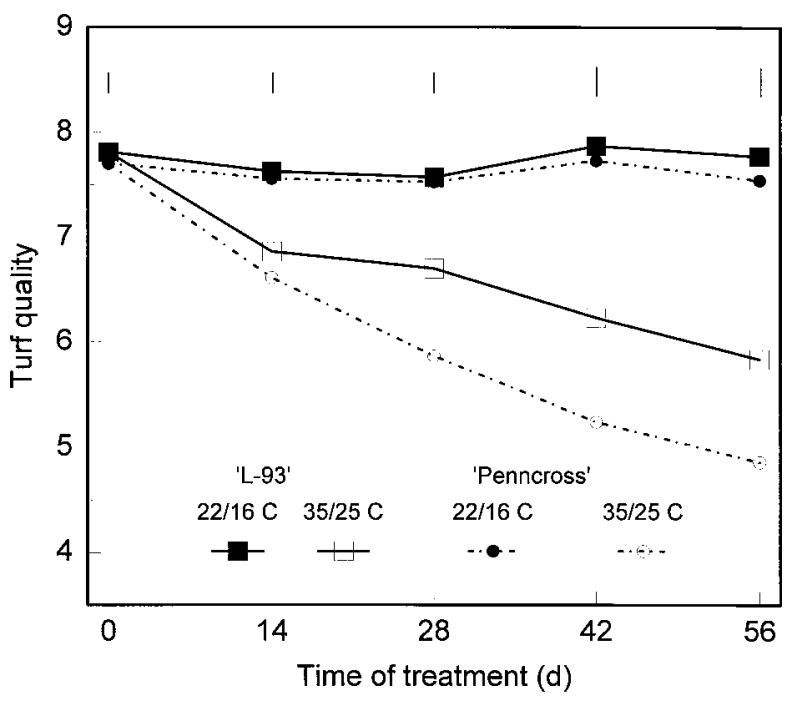

Fig. 1. Turf visual quality of 'L-93' and 'Penncross' creeping bentgrass as affected by temperature. Vertical bars indicate LSD values $(P=0.05)$ for treatment and cultivar comparisons at a given day. Turf quality was rated with a 0 to 9 scale, where $0=$ dead turf and $9=$ best quality with green and turgid leaves.

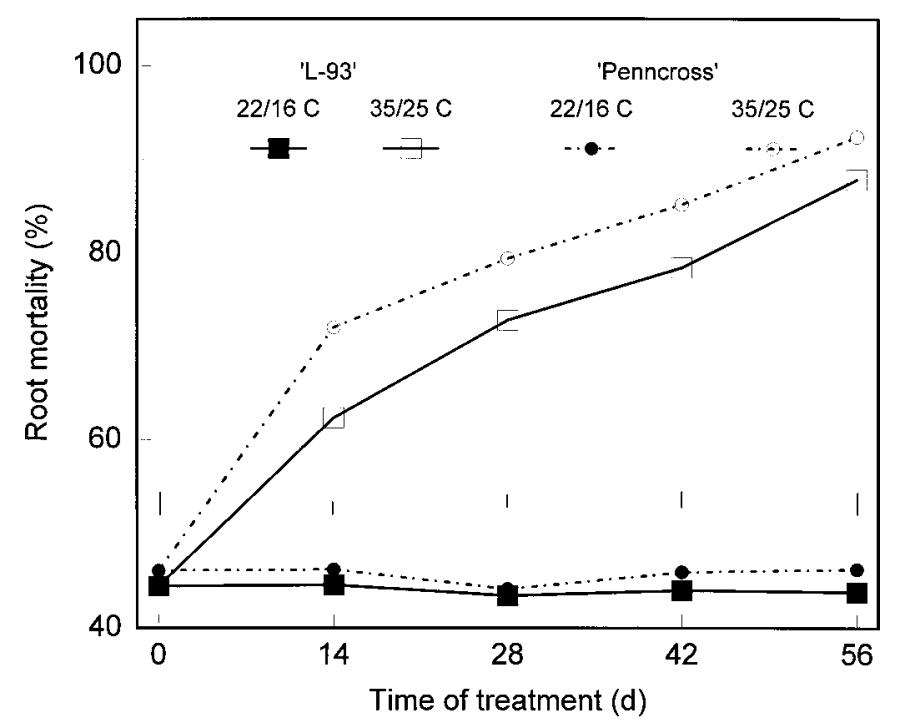

Fig. 2. Root mortality of 'L-93' and 'Penncross' creeping bentgrass as affected by temperature. Vertical bars indicate LSD values $(P=0.05)$ for both treatment and cultivar comparisons at a given day.

procedure for sucrose analysis was similar, except that 10 units/ $\mathrm{mL}$ invertase was used to replace glucose oxidase. The difference in reducing sugar concentration between the solutions with and without invertase was calculated as sucrose concentration.

EXPERIMENTAL DESIGN AND STATISTICAL ANALYSIS. The experiment involved two factors (temperature and cultivar) arranged in a completely randomized design with repeated measurements (Kempthorne, 1952). Each temperature regime was replicated with four growth chambers. Temperature treatments were once reassigned to different growth chambers during the experiment (High temperature chambers were used for low temperature and vice versus). Cultivars were arranged randomly in each growth chamber. At each sampling time, four replicate plants (containers) were selected randomly from each growth chamber.

Data regarding effects of temperature, cultivar, days of sampling (time), and their interactions were subjected to analysis of variance procedures according to the general linear model procedures of SAS (SAS Institute, Inc., Cary, N.C.). Variation was partitioned into cultivar, temperature, and time as main effects and their corresponding interactions. Differences between treatment means were separated by LSD at $P<0.05$.

\section{Results}

All main effects and most interactions were significant at $P<$ 0.05 for all the parameters examined. However, interactions were nonsignificant at $P<0.05$ between cultivar and time for turf quality, shoot sucrose and glucose, root fructans, starch, and glucose, and between cultivar temperature time for turf quality, root TNC, and sucrose (Tables 1 and 2). To define how each cultivar responded to heat stress over time, temperature effects were discussed separately within each cultivar because of the significant interaction of temperature and cultivar.

TURF QUALITY. Turf quality of heat-stressed plants $\left(35 / 25^{\circ} \mathrm{C}\right)$ of both cultivars decreased significantly below the level of control plants $\left(22 / 16^{\circ} \mathrm{C}\right)$, beginning at $14 \mathrm{~d}$ of heat stress (Fig. 1). The decline was more severe for 'Penncross' than for 'L-93'. By $56 \mathrm{~d}$, turf quality had decreased to $75 \%$ of the controls for ' $\mathrm{L}-93$ ' and $68 \%$ for 'Penncross'. At 28, 42, and 56 d of treatment, 'L-93' had significantly greater turf quality than 'Penncross'.

ROOT MORTALITY. Root mortality increased when compared to controls at $14 \mathrm{~d}$ of treatment for both cultivars (Fig. 2). At 14, 28, 42 , and $56 \mathrm{~d}$, root mortality of heat-stressed plants was $40 \%, 67 \%$, $78 \%$, and $100 \%$ higher than that of the control plants, respec-

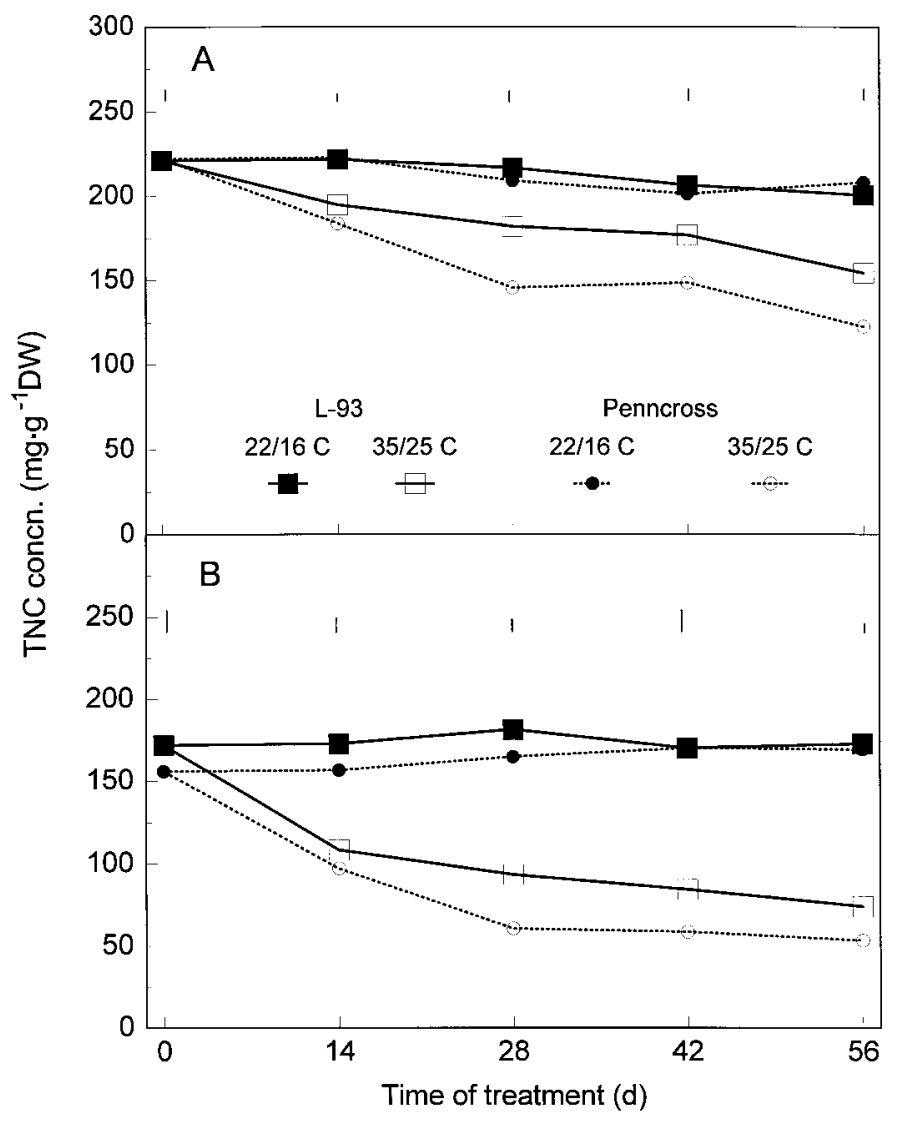

Fig. 3. Total nonstructural carbohydrate (TNC) concentrations in shoots (A) and roots (B) of 'L-93' and 'Penncross' creeping bentgrass as affected by temperature. Vertical bars indicate LSD values $(P=0.05)$ for treatment and cultivar comparisons at a given day. 


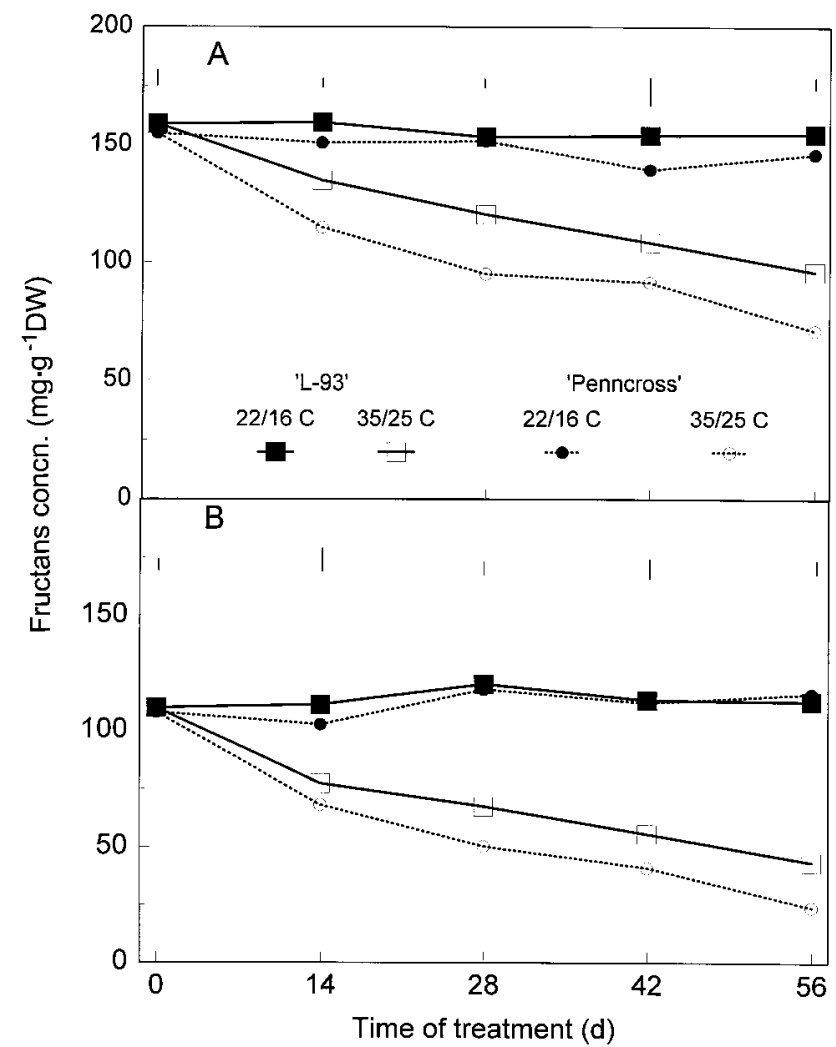

Fig. 4. Fructan concentrations in shoots (A) and roots (B) of 'L-93' and 'Penncross' creeping bentgrass as affected by temperature. Vertical bars indicate LSD values $(P=0.05)$ for treatment and cultivar comparisons at a given day.

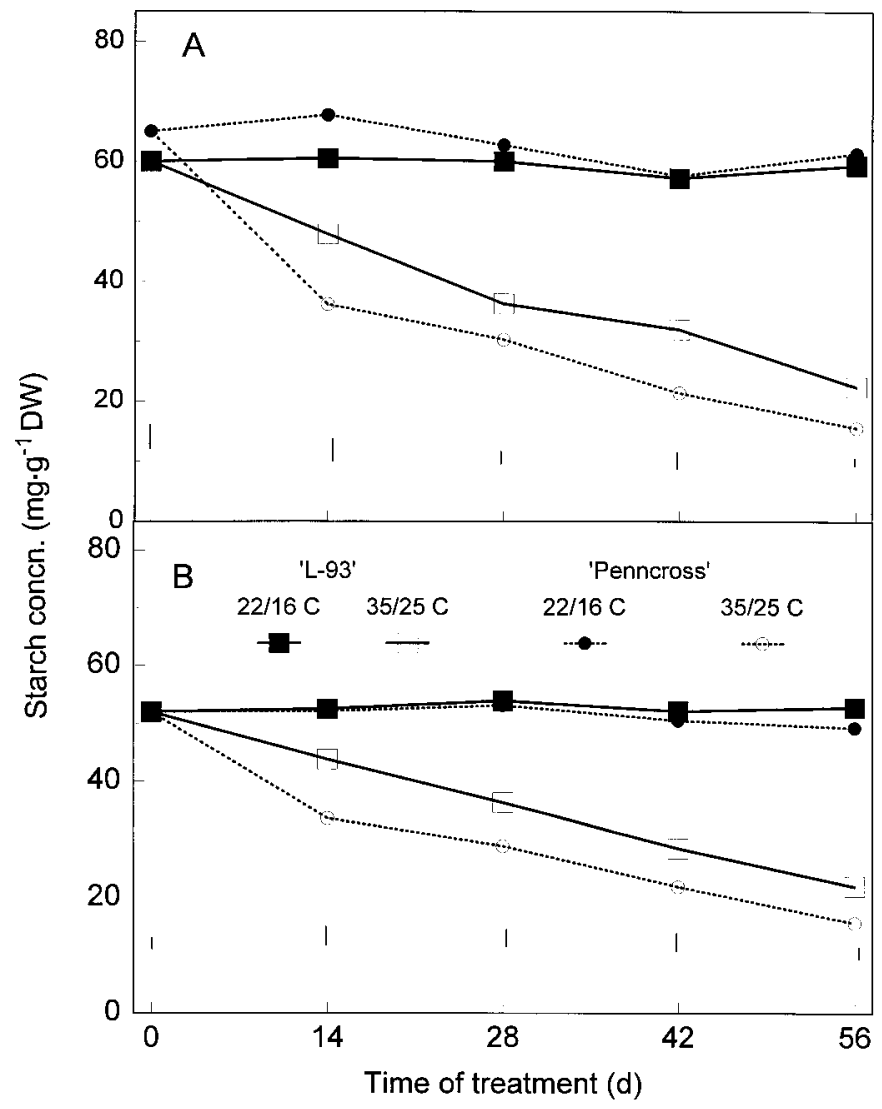

Fig. 5. Starch concentrations in shoots (A) and roots (B) of 'L- 93' and 'Penncross' creeping bentgrass as affected by temperature. Vertical bars indicate LSD values $(P=0.05)$ for treatment and cultivar comparisons at a given day.

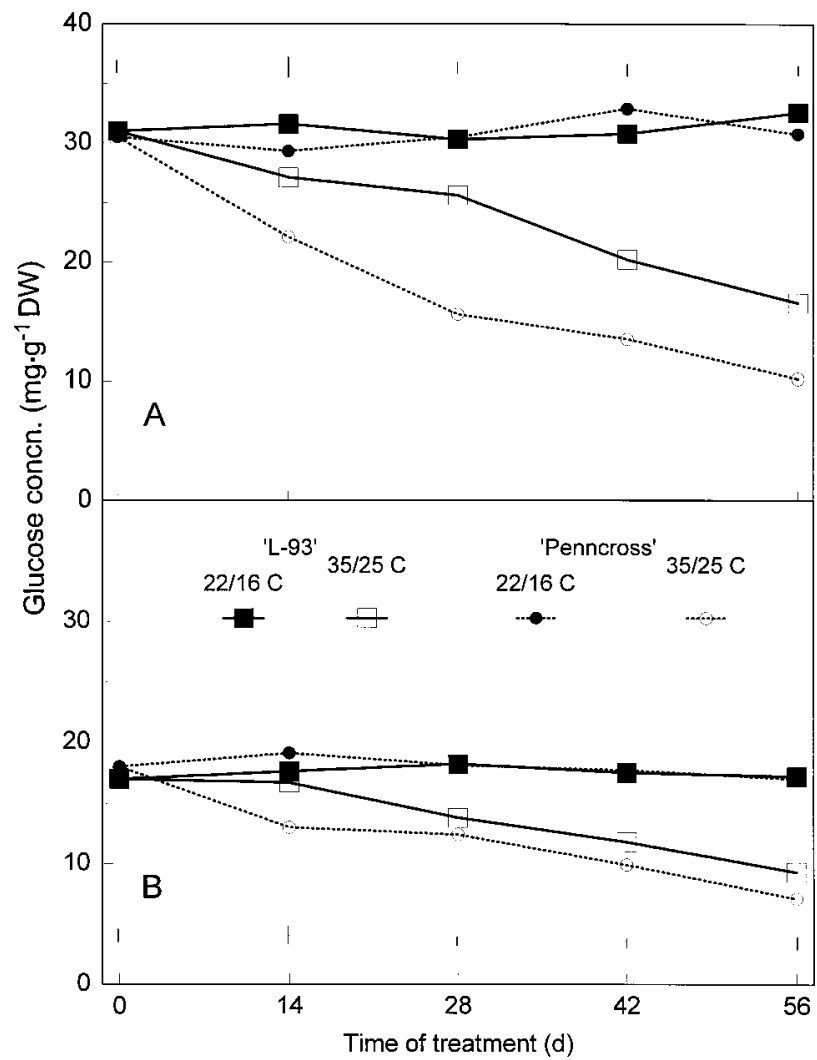

Fig. 6. Glucose concentrations in shoots (A) and roots (B) of 'L-93' and 'Penncross' creeping bentgrass as affected by temperature. Vertical bars indicate LSD values $(P=0.05)$ for treatment and cultivar comparisons at a given day.

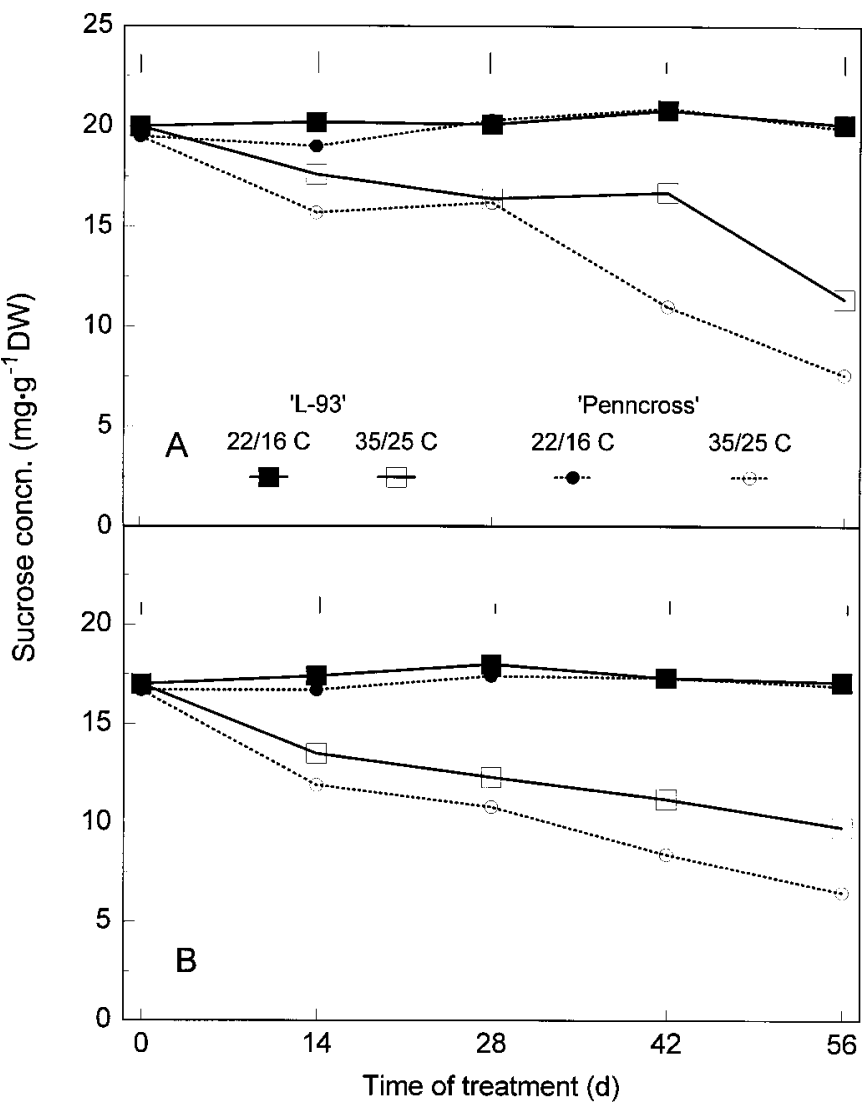

Fig. 7. Sucrose concentrations in shoots (A) and roots (B) of 'L- 93' and Penncross creeping bentgrass as affected by temperature. Vertical bars indicate LSD values $(P=0.05)$ for treatment and cultivar comparisons at a given day. 
tively, for 'L-93', and 56\%, 80\%, 85\%, and 100\%, respectively, for 'Penncross'. Under heat-stress conditions, root mortality was significantly higher for 'Penncross' than for 'L-93'.

TOTAL NONSTRUCTURAL CARBOHYDRATES. TNC in shoots and roots were significantly lower for both cultivars than their respective controls at $14 \mathrm{~d}$ of treatment (Fig. 3). Heat stress, however, caused a greater reduction of TNC concentration in roots (Fig. 3B) than in shoots (Fig. 3A) for both cultivars. TNC concentration in shoots and roots was significantly lower in 'Penncross' than in 'L-93' at 28, 42, and $56 \mathrm{~d}$ of treatment.

FruCtans AND STARCH. Fructans and starch concentrations decreased significantly in both shoots and roots for heat-stressed 'L-93' and 'Penncross', when compared to their respective controls (Figs. 4 and 5). The extent of reduction for fructan concentration was greater in roots (Figs. $4 \mathrm{~B}$ and $5 \mathrm{~B}$ ) whereas that of starch concentration was greater in shoots (Figs. 4A and 5A). Compared to 'Penncross', 'L-93' had significantly higher fructan and starch concentrations in shoots and roots at 14, 28, 42, and 56 $\mathrm{d}$ of treatment. Fructan concentrations were 2 to 3 times that of starch in shoots or roots of both cultivars under control or high temperature conditions (Figs. 4 and 5).

GLuCOSE AND SUCROSE. Heat stress reduced the concentration of glucose (Fig. 6) and sucrose (Fig. 7) in shoots and roots of both cultivars. The magnitude in the reduction of both simple sugars was more dramatic in shoots (Figs. 6A and 7A) than in roots (Figs. 6B and 7B) for 'Penncross'. 'L-93' had significantly higher shoot glucose concentration than 'Penncross' at 14, 28, 42, and $56 \mathrm{~d}$ of treatment. Sucrose concentration was significantly higher for ' $\mathrm{L}$ 93' than 'Penncross' at 14, 42, and $56 \mathrm{~d}$ in shoots and at 14, 28, 42 , and $56 \mathrm{~d}$ in roots. Averaged over the entire heat-treatment period, glucose and sucrose concentrations in shoots of 'L-93' were $50 \%$ and $29 \%$ higher than those of 'Penncross'; glucose and sucrose concentrations in roots were $22 \%$ and $28 \%$ higher for ' $\mathrm{L}$ 93' than for 'Penncross'.

\section{Discussion}

Turf quality decreased and root mortality increased during heat stress in both cultivars. However, the decline in turf quality and increase in root mortality were more severe for 'Penncross' than 'L-93'. These results are consistent with those of previous studies (Huang et al., 1998a, 1998b; Liu and Huang, 2000) that reported greater heat tolerance for 'L-93' than 'Penncross', based on responses of photosynthesis, respiration, electrolyte leakage, membrane lipid peroxidation, and root growth to heat stress. 'L93' also had more tillers per plant than 'Penncross', which may have contributed to higher carbohydrate accumulation and increased heat tolerance in L-93 (Xu and Huang, unpublished results).

The decline in turf quality and accelerated root dieback during heat stress and variations in heat tolerance between the two cultivars could be related to changes in carbohydrate status in shoots and roots. Levels of TNC and components decreased in shoots and roots in both cultivars under heat stress. Heat stress caused more dramatic reductions of glucose and sucrose levels in shoots than in roots for heat sensitive 'Penncross'. Furthermore, heat-tolerant 'L-93' maintained much higher concentrations of fructans, starch, glucose, and sucrose in shoots and roots than 'Penncross' during heat stress. Differences in levels of glucose and sucrose between the two cultivars at high temperature were more pronounced in shoots than in roots. These results suggest that sugar levels in shoots were more sensitive to heat stress than those in roots. Among all carbohydrate components, glucose and sucrose levels in shoots were related more closely to heat tolerance. However, fructans were the dominant carbohydrates in terms of quantity in both cultivars.

Reduction in levels of TNC at high temperatures has been reported in other plant species. Sucrose accumulation decreased significantly during heat stress in winter wheat (Triticum aevistum L.) (Zemanek and Frecer, 1990). Starch concentration was reduced significantly in heat-stressed leaves of Indian mustard (Brassica juncea L.) (Subrahmanyam and Rathore, 1995) and potato (Solanum tuberosum L.) (Lafta and Lorenzen, 1995). Chatterton et al. (1987) reported that concentrations of starch, fructans, and sucrose decreased while glucose concentration remained constant with increasing temperatures in crested wheatgrass [Agropyron cristatum (L.) Gaertn.] and redtop (Agrostis alba L.). Howard and Watschke (1991) reported that fructan concentrations were 2 -fold lower at $30^{\circ} \mathrm{C}$ than at $10^{\circ} \mathrm{C}$ although the sum of glucose, fructose, and sucrose did not change in Kentucky bluegrass during high temperature stress. However, Duff and Beard (1974) reported increased photosynthetic rate and increased level of ethanol and water-soluble sugars in creeping bentgrass with increasing temperatures.

Reduction in carbohydrate accumulation under high temperature conditions may result from the imbalance between photosynthesis and respiration (Huang et al., 1998a; Prange et al., 1990; Wolf et al., 1991). Photosynthetic rate declines and respiration rate increases in many $\mathrm{C}_{3}$ plants with higher temperatures (Huang et al., 1998a; Kobza and Edwards, 1987; Paulsen, 1994). Huang and Gao (2000) and Huang et al., (1998a) reported that canopy respiration rate exceeded photosynthetic rate in creeping bentgrass at $>30{ }^{\circ} \mathrm{C}$. Daily carbon consumption to production ratio was several times higher in heat-stressed plants than control plants (Huang and Gao, 2000). The reduced carbohydrate levels in both shoots and roots may also be caused by increases in photorespiration under heat stress, which reduces photosynthetic efficiency in cool-season species (Nilsen and Orcutt, 1996). Heat-tolerant cultivars appear to minimize the detrimental effects of high temperature by maintenance of a lower respiration rate than that of sensitive cultivars (Deal et al., 1990).

\section{Literature Cited}

Baker, B.S. and G.A. Jung. 1968. Effect of environmental conditions on the growth of four perennial grasses. I. Response to controlled temperature. Agron. J. 60:155-158.

Beard, J.B. 1973. Temperature, p. 209-260. In: J.B. Beard (ed.). Turfgrass: Science and culture. Prentice-Hall, Englewood Cliffs, N.J.

Beard, J.B. 1997. Dealing with heat stress on golf course turf. Golf Course Manager 65:54-59.

Beard, J.B. and W.H. Daniel. 1965. Effect of temperature and cutting on the growth of creeping bentgrass (Agrostis palustris Huds.) roots. Agron. J. 57:249-250.

Carrow, R.N. 1996. Summer decline of bentgrass greens. Golf Course Manager 64:51-56.

Chatterton, N.J., P.A Harrison, J.H. Bennett, and W.R. Thornley. 1987. Fructosan, starch and sucrose concentrations in crested wheatgrass and redtop as affected by temperature. Plant Physiol. Biochem. 25:617623.

Deal, D.L., J.C. Raulston, and L.E. Hinesley. 1990. High temperature effects on apical bud morphology, dark respiration, and fixed growth of blue spruce. Can. J. For. Res. 20:1871-1877.

DiPaola, J.M. and J.B. Beard. 1992. Physiological effects of temperature stress, p. 231-262. In: D.V. Waddington, R.N. Carrow, and R.C. Shearman (eds.). Amer. Soc. Agron. Turfgrass Monogr. 32. 
Duff, D.T. and J.B. Beard. 1974. Supraoptimal temperature effects upon Agrostis palustris. Part II. Influence on carbohydrate levels, photosynthetic rate, and respiration rate. Physiol. Plant. 32:18-22.

Hoagland, D.R. and D.I. Arnon. 1950. The water-culture method for growing plants without soil. Calif. Agr. Expt. Sta. Circ. 347.

Howard, H.F. and T.L. Watschke. 1991. Variable high-temperature tolerance among Kentucky bluegrass cultivars. Agron. J. 83:689-693.

Huang, B. and H. Gao. 2000. Growth and carbohydrate metabolism of creeping bentgrass cultivars in response to increasing temperatures. Crop Sci. (in press).

Huang, B., X. Liu, and J.D. Fry. 1998a. Shoot physiological responses of two bentgrass cultivars to high temperature and poor soil aeration. Crop Sci. 38:1219-1244.

Huang, B., X. Liu, and J.D. Fry. 1998b. Effects of high temperature and poor soil aeration on root growth and viability of creeping bentgrass. Crop Sci. 38:1618-1622.

Kempthorne, O. 1952. The design and analysis of experiments. Wiley, New York.

Knievel, D.P. 1973. Procedures for estimating ratio of live or dead root dry matter in root core samples. Crop Sci. 13:124-126.

Kobza, J. and G.E. Edwards. 1987. Influences of leaf temperature on photosynthetic carbon metabolism in wheat. Plant Physiol. 83:69-74.

Krans, J.V. and G.V. Johnson. 1974. Some effects of subirrigation on bentgrass during heat stress in the field. Agron. J. 66:526-530.

Lafta, A.M. and J.H. Lorenzen. 1995. Effect of high temperature on plant growth and carbohydrate metabolism in potato. Plant Physiol. 109:637643.

Liu, X. and B. Huang. 2000. Heat stress injury in relation to membrane lipid peroxidation in creeping bentgrass. Crop Sci. (in press).

Nilsen, E.T. and D.M. Orcutt. 1996. Physiology of plants under stress: Abiotic stress. Wiley, New York.
Paulsen, G.M. 1994. High temperature responses of crop plants, p. 365389. In: K.J. Boote, J.M. Bennett, T.R. Sinclair, and G.M. Paulsen (eds.). Physiology and determination of crop yield. Amer. Soc. Agron.Crop Sci. Soc. Amer.-Soil Sci. Soc. Amer., Madison, Wis.

Prange, R.K., K.B. McRae, D.J. Midmore, and R. Deng. 1990. Reduction in potato growth at high temperature: Role of photosynthesis and dark respiration. Amer. Potato J. 67:357-369.

Subrahmanyam D. and V.S. Rathore. 1995. High temperature influences ${ }^{14} \mathrm{CO}_{2}$ assimilation and allocation of ${ }^{14} \mathrm{C}$ into different biochemical fractions in the leaves of Indian mustard. J. Agron. Crop Sci. 169:169_ 175

Watschke T.L., R.E. Schmidt, and R.E. Blaser. 1970. Responses of some Kentucky bluegrasses to high temperature and nitrogen fertility. Crop Sci. 10:372-376.

Wehner, D.J. and T.L. Watschke. 1981. Heat tolerance of Kentucky bluegrass, perennial ryegrass, and annual bluegrass. Agron J. 73:7984.

Westhafer M.A., J.T. Law, and D.T. Duff. 1982. Carbohydrate concentration and relationships with $\mathrm{N}$ nutrition in cool-season turfgrass. Agron. J. 74:270-274.

Wolf, S., A. Marani, and J. Rudich. 1991. Effect of high temperature on carbohydrate metabolism in potato plants. J. Expt. Bot. 42:619-625.

Youngner, V.B. and F.J. Nudge. 1968. Growth and carbohydrate storage of three Poa pratensis L. strains as influenced by temperature. Crop Sci. 8:455-457.

Youngner, V.B. and F.J. Nudge. 1976. Soil temperature, air temperature, and defoliation effects on growth and nonstructural carbohydrates of Kentucky bluegrass. Agron. J. 68:257-260.

Zemanek M. and R. Frecer. 1990. The influence of high temperatures on saccharose accumulation in the grain of winter wheat genotypes. Rostlinna Vyroba 36:965-976. 